\title{
Aryl removal methods and passion fruit seed positions: Germination and emergence ${ }^{1}$
}

\author{
Sérgio Macedo Silva², Roberta Camargos de Oliveira², \\ Risely Ferraz de Almeida ${ }^{3}$, Adílio de Sá Júnior ${ }^{2 *}$, Carlos Machado dos Santos ${ }^{2}$
}

\begin{abstract}
Yellow passion fruit has conquered a significant position in the agribusiness of tropical fruits; therefore, farmers have been interested in expanding their groves, and technical information that guarantees the high yield of the farmings is needed. Aiming to observe factors related to the propagative material targeted at quality and maximization of the genetic potential, the objective of the study consisted in assessing germination and emergence of passion fruit seeds collected in three positions in the fruits and submitted to different methods of mucilage removal (aryl). The passion fruits were split in three parts: distal, medial and proximal and the contents of each part was divided in two. The content of each part of the fruit was submitted to mechanical and by fermentation methods for removal of aryl. It is concluded that the seed position in the fruit does not interferes with the germination. The aryl removal method by mechanical extraction affects the germination and seedling emergence.
\end{abstract}

Index terms: Passiflora edulis, mechanical extraction, fermentation, propagation, mucilage.

\section{Métodos de remoção do arilo e posições das sementes no fruto de maracujá: Germinação e emergência}

\begin{abstract}
RESUMO - O maracujá-amarelo conquistou significativa posição no agronegócio de frutas tropicais, com isso, produtores despertaram interesse para expandir seus pomares, sendo necessárias informações técnicas que garantam a alta produtividade das lavouras. No intuito de observar fatores relacionados ao material propagativo visando a qualidade e a maximização do potencial genético objetivou-se avaliar a germinação e a emergência de sementes de maracujá coletadas em três posições nos frutos e submetidas a métodos de retirada da mucilagem (arilo). Os frutos de maracujá foram seccionados em três partes: distal, mediana e proximal. Cada um destes conteúdos foi submetido aos métodos mecânico e de fermentação para remoção do arilo. Podendo concluir que a posição da semente no fruto do maracujazeiro não interfere na germinação e o método de remoção do arilo por extração mecânica prejudica a germinação e a emergência de plântulas.
\end{abstract}

Termos para indexação: Passiflora edulis, extração mecânica, fermentação, propagação, mucilagem.

\section{Introduction}

Passion fruit, Passiflora edulis Sims f. flavicarpa Degener, is a species widely marketed both for processing and for consumption "in natura" (Zeraik et al., 2010). The high price of yellow passion fruit juice in the international market has made this species achieve a higher position in the agribusiness of tropical fruits and, therefore, it has raised interest for farmers in expanding their groves (Meletti et al., 2002; Almeida, 2012a).

Investment in seedlings and/or selected seeds is an important component of the production process as it is a fundamental prerequisite to the success of the activity, especially in projects aimed at achieving the noblest portions

${ }^{1}$ Submitted on $02 / 24 / 2015$. Accepted for publication on $05 / 25 / 2015$.

${ }^{2}$ Universidade Federal de Uberlândia, Instituto de Ciências Agrárias, Caixa Postal 593, 38400-902 - Uberlândia, MG, Brasil. of the consumer market, such as exports (David et al., 1999).

Passion fruit seedlings may be obtained by means of seeds or vegetative state through root cuttings. Sowing takes precedence over the asexual method due to the ease of the process and the shorter period for forming the seedlings. However, care should be taken since germination problems are very common in the Passiflora genus (Lima et al., 2006).

Usually the spread is carried out without regard to factors related to the steps between harvesting and sowing. As a consequence, low percentage of germination, little vigorous plants, low crop yield and great variability in the physical characteristics of the fruits can occur (Carlesso et al., 2008).

In this regard, in order to obtain seedlings in greater

${ }^{3}$ Universidade Estadual Paulista Júlio de Mesquita Filho, Caixa Postal 237, 18610-307 - Jaboticabal, SP, Brasil.

*Corresponding author <adilio.junior@yahoo.com.br> 
quantity and better quality, studies with passion fruit seeds are needed, in all sectors of seed technology. This knowledge would ensure high crop yields (Meletti et al., 2002).

Removal of aryl is directly related to methods for obtaining high quality seeds (Aguiar et al., 2014; Araújo et al., 2015). Besides other techniques conducted in the development of plants, such as pruning (Almeida, 2012a), soil fertilization (Almeida, 2012b), seed storage (Araújo et al., 2009) and the use of a suitable substrate in seedling formation (Wagner Junior et al., 2007; Aguiar et al., 2014).

The germination behavior and the emergence of passion fruit seeds as well as the position of the seeds in the fruits and the methods for removal of aryl were the focus of this study. In Brazil, research on seed technology in fruit species are uncommon (Osipi et al., 2011). In this sense, the objective was to assess the germination and emergence of passion fruit seeds collected in three positions in fruits and subjected to mucilage removal methods (aryl).

\section{Material and Methods}

\section{Characterization of the experiment}

The experiment was carried out in the Seeds Laboratory of Federal University of Uberlândia, city of Uberlândia, Minas Gerais, MG, Brazil. Passion fruits were collected in a clonal grove in the city of Araguari, MG, obtained in the same position in plants, maturation stage and uniform format, weighing from 20 to 22 g.fruit $^{-1}$ (Figure 1A).The experiment was established in a a randomized block design (RBD) with four replications; treatments were distributed in a $(3 \times 2+2)$ factorial arrangement, whose first factor was the seed position in the fruit (distal, medial and proximal), Figure 1B, the second factor was the aryl removal mode (mechanical and fermentation) and additional treatments consisting of seeds of all the fruit with aryl removal by the fermentation method (additional 1) and mechanical (additional 2).
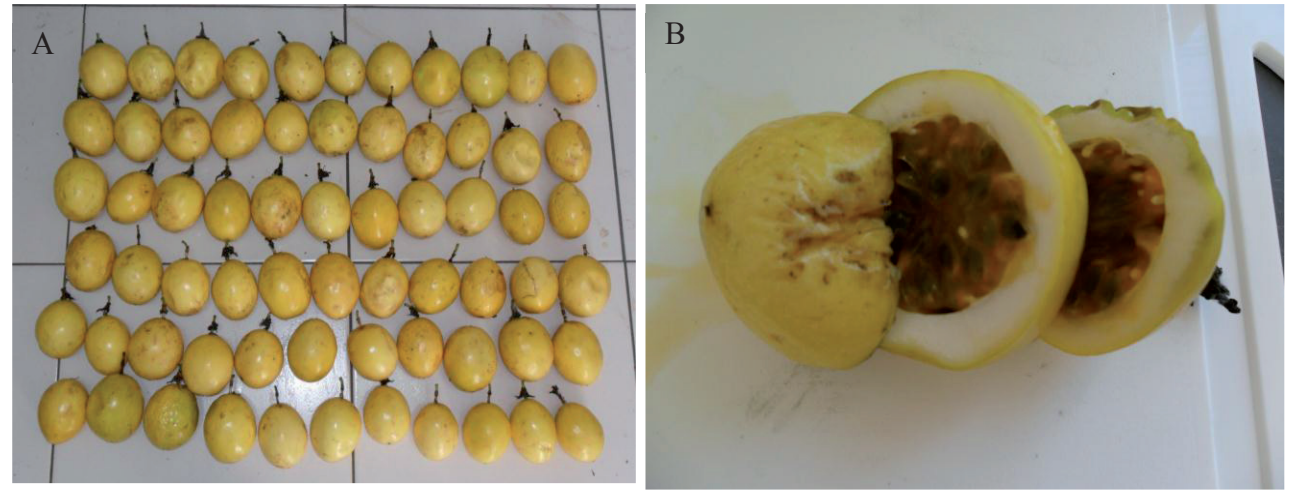

Figure 1. (A) Passion fruit (Passiflora edulis) collected and standardized for the treatments. (B) Details of the seed positions in passion fruit: distal, medial and proximal.

\section{Experiment design}

The fruits, after sectioned and removed the contents of each part, were divided into two equal parts, which were subjected to mechanical and fermentation methods for aryl removal.

In the aryl mechanical extraction method the seeds were first centrifuged at $200 \mathrm{rpm}$ per minute. Subsequently, mucilage was separated from the seeds and washed to remove traces and placed to dry in the shade at room temperature for 24 hours.

The removal by the seeds fermentation method was accomplished using the $10 \%$ solution of slaked lime (calcium hydroxide), as recommended by Osipi et al. (2011). After 48 hours, seeds were washed in water to remove lime. Subsequently they were placed to dry under the same conditions of the seeds prepared by the mechanical method.

The seeds germination test was carried out using germitest paper substrate, moistened with a water volume (mL) 2.5 times the weight of the dry paper in grams. 50 seeds were sown per plot, using two sheets of paper in rolls that were placed in a Mangelsdorf germinator, set at an alternating temperature between 25 and $30{ }^{\circ} \mathrm{C}$ and 8 hours of light, as done by Bornhofen et al. (2015).

The emergence test was conducted in tubes used in commercial seedling formation. Trays were used with 96 tubes with a volumetric capacity of $110.0 \mathrm{~cm}^{3}$, filled with Plantimax ${ }^{\circledR}$ substrate, and the plot was made up of 16 tubes. Sowing was done manually by placing three seeds at a depth of $0.5 \mathrm{~cm}$. Then the trays were transferred to the greenhouse. 


\section{Variables analyzed}

Germination assessments were on the 7th and 28th days after sowing. The seedlings were classified into normal and non-germinated seeds (hard, numb and dead).

The percentage of emergence count was performed at intervals of eight hours from the emergence of the first seedling until the stabilization that occurred thirty days after sowing. This procedure was carried out according to the Rules for Seed Testing (Brasil, 2009), considering as emerged seedling the one that had expanded cotyledons, as described by Osipi et al. (2011).

The emergence speed index (ESI) seeds was performed according to the formula proposed by Maguire (1962), Equation 1: where $\mathrm{Ngi}$ refers to the number of seeds germinated on day i.; $\mathrm{Ti}$ : the time in days after sowing to germination. This equation was also tested for other species such as Archontophoenix cunninghamii, popularly known in Brazil as seafórtia (Pivetta et al., 2008) and cotton seeds, Gossypium hirsutum L. (Faria et al., 2003).

$$
I V E=\frac{\sum N g i}{T i}
$$

The mean emergence time (MET) was calculated using the formula proposed by Bianchetti and Amaral (1978), by emergence percentage ratio by the emergence speed index (ESI). Whereas to calculate the average speed of germination was used the formula proposed by Throneberry and Smith (1956).

\section{Statistical analyses}

The results of the variables were submitted to the waste normality tests (Shapiro-Wilk test, SPSS Inc., USA) and homogeneity of variances (Bartlett test, SPSS Inc., USA) and additivity of the blocks to check the quality of the database.

Then the variables were subjected to analysis of variance (ANOVA) and when $\mathrm{H} 0$ was rejected averages were compared by Tukey test at 0.05 probability (Sisvar Inc., Brasil), according to the recommendations from Ferreira (2011).

\section{Results and Discussion}

There was a distinction between the methods for seed extraction. Fermentation allowed better germination percentage, unlike the mechanically aryl removal. Values of $82.0 \%$ of germination obtained by treatment with fermentation (Figure 2) were similar to those obtained by Martins et al. (2006), who have also assessed the influence of fermentation in seed viability.

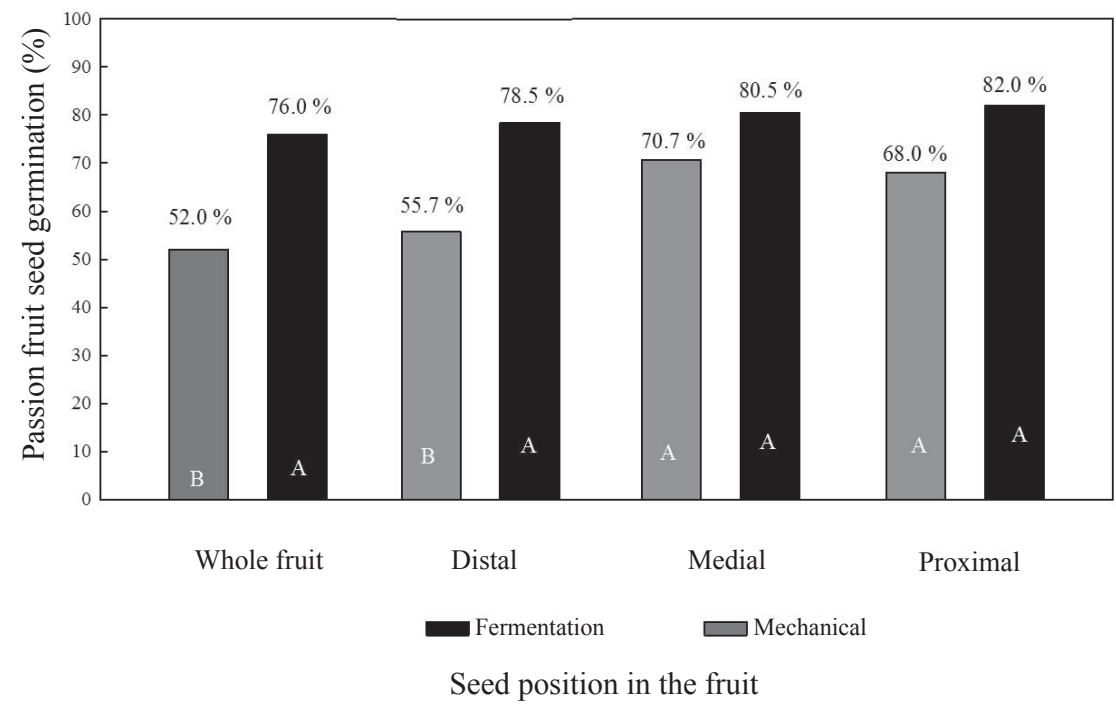

Figure 2. Seed germination (\%) of Passiflora edulis in relation to the seed position in the fruit (distal, medial and proximal), aryl removal (by fermentation and mechanical) and control treatment (whole fruit). Figure: Means followed by the same letter are not statistically different from each other by Tukey test at $5 \%$ probability. (Coefficient of variation ( $\%)$ : 11.84; Significant average difference: 16.78).

The use of lime in the fermentation allowed for the maintenance of the germination potential when compared to mechanical extraction, since in this method damage to the seed coat occurs (Martins et al., 2006; Cardoso et al., 2001). According to Cardoso et al. (2001) lime helps remove the mucilage (aryl) without harming emergence. 
Aryl adhering to the seeds attracts microorganisms due to its chemical composition. These may promote the destruction of the barrier in immediate contact with the seed, which promotes germination (Osipi et al., 2011).

The presence of aryl is related to the exposure of the seeds to very negative water potential, which hinders the absorption of water by the seeds and hence prolongs the early stages of germination. Furthermore, the presence of unsaturated triglycerides in the aryl form a barrier to the water inlet and the presence of steroids, which may act as hormones, compete for the active site and/or inhibit the action of hormones necessary for the germination and contained in the seeds (Martins et al., 2010).

Thus, seeds without aryl contribute to a higher percentage of normal seedlings, ensuring higher germination rates and an inverse relationship of aryl presence with the harshness of seeds (Lopes et al., 2007).

Mechanical aryl extraction damages the integument of passion fruit seeds; then the final yield of seeds is reduced. In the intense damage, the seeds are discarded or do not germinate; as for light damage, there is a decrease in the genetic potential to produce high vigor seedlings. This is because lesions or damage to the seed coat, endosperm and embryo disrupt the water absorption and, therefore, all the initial germination stages are changed. In the long term, this is reflected in the field, in lower yield and/or delay in fruiting.

For non-germinated seeds (hard, numb and dead) statistical assessment was not performed due to low occurrence; in this case, as the incidence was timely, the application of mathematical tests could express unrealistic results, proven by the high coefficient of variation.

Regarding the emergence test, treatment with the extraction of seeds by the fermentation method had higher means. The significant difference was observed in the distal and proximal areas for the emergence (E) and emergence speed index (ESI), respectively $85.93 \%$ and 0.04053 for distal, and $90.62 \%$ and 0.03861 for proximal. The mean emergence time (MET) for the mechanical treatment showed a small increase of $7.87 \%$ relative to fermenting (for additionals). Between additional treatments had significant difference just for the variable ESI (Table 1). This result is due to characteristics of Passifloraceae that are considered among the families whose seeds present dormancy due to water inlet control mechanisms into it. One can attribute this effect to a possible interference of fermentation in this process (Cardoso et al., 2001).

Table 1. Emergence (E), emergence speed index (ESI), average emergence speed (AES), mean emergence time (MET) of Passiflora edulis seedlings in relation to seed position in the fruit (distal, medial and proximal), aryl (mechanical and by fermentation) removal, and additional with mechanical removal (A1) and fermentation (A2).

\begin{tabular}{llcccc}
\hline Position & Aryl removal method & E $(\%)$ & ESI & AES & MET (h) \\
\hline \multirow{2}{*}{ Distal } & Mechanical & $40.62 \mathrm{~b}$ & $0.01704 \mathrm{~b}$ & $0.00243 \mathrm{a}$ & $420.99 \mathrm{a}$ \\
& Fermentation & $85.93 \mathrm{a}$ & $0.04053 \mathrm{a}$ & $0.00279 \mathrm{a}$ & $360.42 \mathrm{a}$ \\
Medial & Mechanical & $65.62 \mathrm{a}$ & $0.02745 \mathrm{a}$ & $0.00244 \mathrm{a}$ & $411.05 \mathrm{a}$ \\
& Fermentation & $95.31 \mathrm{a}$ & $0.04170 \mathrm{a}$ & $0.00257 \mathrm{a}$ & $389.75 \mathrm{a}$ \\
Proximal & Mechanical & $43.75 \mathrm{~b}$ & $0.01754 \mathrm{~b}$ & $0.00169 \mathrm{a}$ & $339.06 \mathrm{a}$ \\
& Fermentation & $90.62 \mathrm{a}$ & $0.03861 \mathrm{a}$ & $0.00244 \mathrm{a}$ & $415.95 \mathrm{a}$ \\
A1 & Mechanical & $57.81 \mathrm{a}$ & $0.02323 \mathrm{~b}$ & $0.00237 \mathrm{a}$ & $422.79 \mathrm{a}$ \\
A2 & Fermentation & $90.62 \mathrm{a}$ & $0.03989 \mathrm{a}$ & $0.00258 \mathrm{a}$ & $391.91 \mathrm{a}$ \\
\hline $\mathrm{SAD}^{1}$ & & 36.39 & 0.01584 & 0.00092 & 186.46 \\
$\mathrm{CV}^{2}(\%)$ & & 25.37 & 25.61 & 18.99 & 23.52 \\
\hline
\end{tabular}

${ }^{1} \mathrm{SAD}$ : significant average difference; ${ }^{2} \mathrm{CV}$ : Coefficient of variation. Means followed by similar letters are not statistically different from each other by Tukey test at $5 \%$ probability for the aryl removal method.

ESI of the seeds is important because it determines the seed lot vigor both in field conditions as in a greenhouse (Oliveira et al., 2009). The more vigorous the seed lot, the faster the seedling emergence will be (Aguiar et al., 2014) and the greater the speed in the metabolic processes of the plant; consequently, there will be a faster and more uniform emission of the primary root in the germination process (Munizzi et al., 2010).

Among the positions of seeds in the fruit there was no significant difference for variables AES and MET, obtaining better results in the medial position, with averages of 0.002 and 400.4, respectively. Similar results were found by Freitas et al. (2013), when working with Mimosa caesalpiniifolia.

However, in other species such as: Moringa oleifera Lam (Oliveira et al., 2013) and Caesalpinia ferrea Mart ex Tul (Nogueira et al., 2010) difference occurs between seed positions in the fruit (Marcos-Filho, 2005). 


\section{Conclusions}

Passion fruit seed position does not interfere with germination. The aryl removal method by mechanical extraction affects the germination and seedling emergence.

\section{Acknowledgments}

The authors thank Conselho Nacional de Desenvolvimento Científico e Tecnológico (CNPq; National Counsel of Technological and Scientific Development) and Coordenação de Aperfeiçoamento de Pessoal de Nível Superior (CAPES; Coordination of Improvement of Higher Education) for supporting the research.

\section{References}

AGUIAR, R.S.; YAMAMOTO, L.Y.; PRETI, E.A.; SOUZA, G.R.B.; SBRUSSI, C.A.G.; OLIVEIRA, E.A.P.; ASSIS, A.M.; ROBERTO, S.R.; NEVES, C.S.V.J. Extração de mucilagem e substratos no desenvolvimento de plântulas de maracujazeiro-amarelo. Semina: Ciências Agrárias, v.35, n.2, p.605-612, 2014. http://www.uel.br/revistas/uel/index.php/semagrarias/ article/view/10418/pdf_261

ALMEIDA, R.F. Características da poda em maracujazeiro. Revista Verde de Agroecologia e Desenvolvimento Sustentável, v.7, n.5, p.53-58, 2012a. http://gvaa.com.br/revista/index.php/RVADS/article/viewFile/1156/pdf 619

ALMEIDA, R.F. Nutrição de maracujazeiro. Revista Verde de Agroecologia e Desenvolvimento Sustentável, v.7, n.3, p.12-17, 2012b. http://www.gvaa. com.br/revista/index.php/RVADS/article/view/1155/pdf_545

ARAÚJO, L.R.; ALVES, E.U.; RODRIGUES, C.M.; RODRIGUES, A.A.M. Emergência e crescimento inicial de plântulas de Eugenia jambolana Lam. após remoção da polpa. Revista Ciência Rural, v.45, n.1, p.14-18, 2015. http://www.scielo.br/pdf/cr/v45n1/0103-8478-cr-45-01-00014.pdf

ARAÚJO, E.C.; SILVA, R.F.; BARROSO, D.G.; CARVALHO, A.J.C. Efeito do armazenamento e do progenitor masculino sobre a qualidade e micromorfologia de sementes de maracujá. Revista Brasileira de Sementes, v.31, n.4, p.110-119, 2009. http://www.scielo.br/pdf/rbs/v31n4/13.pdf

BIANCHETTI, A.; AMARAL, E. Dia médio e velocidade de germinação de sementes de cebola (Allium cepa L.). Pesquisa Agropecuária Brasileira, v.13, p.33-44, 1978. http://seer.sct.embrapa.br/index.php/pab/article/view/16748

BORNHOFEN, E.; BENIN, G; GALVAN, D; FLORES, M.F. Épocas de semeadura e desempenho qualitativo de sementes de soja. Revista Pesquisa Agropecuária Tropical, v. 45, n.1, p. 46-55, 2015. http://www.scielo.br/pdf/ pat/v45n1/1983-4063-pat-45-01-0046.pdf

BRASIL. Ministério da Agricultura, Pecuária e Abastecimento. Regras para análises de sementes. Ministério da Agricultura, Pecuária e Abastecimento. Secretaria de Defesa Agropecuária. Brasília: MAPA/ACS, 2009. 395p. http:// www.agricultura.gov.br/arq_editor/file/2946_regras_analise_sementes.pdf

CARDOSO, G.D.; TAVARES, J.C.; FERREIRA, R.L.F.; CÂMARA, F.A.A.; CARMO, G.A. Desenvolvimento de mudas de maracujazeiro-amarelo obtidas de sementes extraídas por fermentação. Revista Brasileira de Fruticultura, v.23, n.3, p.639-642, 2001. http://www.scielo.br/pdf/rbf/v23n3/8042.pdf
CARLESSO, V.O.; BERBERT, P.A.; SILVA, R.F.; DETMANN, E. Secagem e armazenamento de sementes de maracujá amarelo (Passiflora edulis Sims f. Alavicarpa Degener). Revista Brasileira de Sementes, v.30, n.2, p.065-074, 2008. http://www.scielo.br/pdf/rbs/v30n2/a09v30n2.pdf.

DAVID, D.V.; SILVA, J.M.A.; SILVA, P.M. (Coord.). Diagnóstico de produção e comercialização de mudas e semente de espécies frutíferas na região Nordeste do Brasil. Viçosa, MG: UFV; 1999. 215p. http://www.scielo. $\mathrm{br} / \mathrm{pdf} / \mathrm{rbs} / \mathrm{v} 25 \mathrm{n} 1 / 19640 . \mathrm{pdf}$

FARIA, A.Y.K.; ALBUQUERQUE, M.C.F.; CASSETARI NETO, D Qualidade fisiológica de sementes de algodoeiro submetidas a tratamentos químico e biológico. Revista Brasileira de Sementes, v.25, n.1, p.121-127, 2003. www.abrates.org.br/revista/artigos/2003/v25n1/artigo19.pdf

FERREIRA, D. F. Sisvar: a computer statistical analysis system. Ciência e Agrotecnologia, v.35, n.6, p.1039-1042, 2011. http://www.scielo.br/pdf/ cagro/v35n6/a01v35n6.pdf

FREITAS, T.P.; FREITAS, T.A.S.; CAMPOS, B.M.; FONSECA, M.D.S.; MENDONÇA, A.V.R. Morfologia e caracterização da germinação em função da posição das sementes no fruto de sabiá. Scientia Plena, v.9, n.3, p.1-9, 2013. http://scientiaplena.org.br/sp/article/view/790/670

LIMA, A.A.; CALDAS, R.C.; SANTOS, V.S. Germinação e crescimento de espécies de maracujá. Revista Brasileira de Fruticultura, v.28, n.1, p.125127, 2006. http://www.scielo.br/pdf/rbf/v28n1/29708.pdf

LOPES, J.C.; BONO, G.M.; ALEXANDRE, R.S.; MAIA,V.M. Germinação e vigor de plantas de maracujazeiro-amarelo em diferentes extratos de maturação do fruto, arilo e substrato. Ciência e Agrotecnologia, v.31, n.5, p.1340-1346, 2007. http://www.scielo.br/pdf/cagro/v31n5/10.pdf

MAGUIRE, J.D. Speed of germination-aid in selection and evaluation for seedlingemergence and vigor. Crop Science, v.2, n.1, p.176-177, 1962.

MARCOS-FILHO, J. Fisiologia de sementes de plantas cultivadas. Piracicaba: FEALQ, 2005. 495p

MARTINS, M.R.; REIS, M.C.; NETO, J.A.M.; GUSMÃO, L.L.; GOMES, J.J.A. Influência de diferentes métodos de remoção do arilo na germinação de sementes de maracujazeiro-amarelo (Passiflora edulis Sims F. flavicarpa Deg). Revista da FZVA, v.13, n.2, p. 28-38, 2006. http://revistaseletronicas. pucrs.br/ojs/index.php/fzva/article/view/2362/1849

MARTINS, C.M.; VASCONCELLOS, M.A.S; ROSSETTO, C.A.V ; CARVALHO, M.G. Prospecção fitoquímica do arilo de sementes de maracujáamarelo e influência em germinação de sementes. Ciência Rural, v.40, n.9, p.1934-1940, 2010. http://www.scielo.br/pdf/cr/v40n9/a720cr2740.pdf

MELETTI, L.M.M.; FURLANI, P.R.; ÁLVARES, V.; SOARES-SCOTT, M.D.; BERNACCI, L.C.; AZEVEDO FILHO, J.A. Novas tecnologias melhoram a produção de mudas de maracujá. O Agronômico, v.54, n.1, p.30-33, 2002. http://www.iac.sp.gov.br/publicacoes/agronomico/pdf/541 08t72.pdf

MUNIZZI, A.; BRACCINI, A.L.; RANGEL, M.A.S.; SCAPIM, C.A.; BARBOSA, M.C.; ALBRECHT, L.P. Qualidade de sementes de quatro cultivares de soja, colhidas em dois locais no estado de Mato Grosso do Sul. Revista Brasileira de Sementes, v.32, n.1, p.176-185, 2010. http://www. scielo.br/pdf/rbs/v32n1/v32n1a20.pdf

NOGUEIRA, N.W.; MARTINS, H.V.G.; BATISTA, D.S.; RIBEIRO, M.C.C.; BENEDITO, C.P. Grau de dormência das sementes de jucá em função da posição na vagem. Revista Verde de Agroecologia e Desenvolvimento Sustentável, v.5, n.1, p.39-42, 2010. http://www.gvaa.com.br/revista/index. php/RVADS/article/viewFile/242/242 
OLIVEIRA, A.C.S.; MARTINS, G.N.; SILVA, R.F.; VIEIRA, H.D. Testes de vigor em sementes baseados no desempenho de plântulas. Inter Science Place, v.2, n.4, 2009. Disponível em: < http:/www.interscienceplace.org/ interscienceplace/article/view/37/43 $>$. Accessed on: Jan. 12 ${ }^{\text {th }}, 2015$.

OLIVEIRA, F.A.; OLIVEIRA, M.K.T.; SILVA, R.C.P.; SILVA, O.M.P.; MAIA, P.M.E.; CÂNDIDO, W.S. Crescimento de mudas de moringa em função da salinidade da água e da posição das sementes nos frutos. Revista Árvore, v. 37 , p.79-87, 2013. http://www.scielo.br/pdf/rarv/v37n1/v37n1a09.pdf

OSIPI, E.A.F; LIMA, C.B.; COSSA, C.A. Influência de métodos de remoção do arilo na qualidade fisiológica de sementes de Passiflora alata Curtis. Revista Brasileira de Fruticultura, v.33, n.1, p.680-685, 2011. http://www. scielo.br/pdf/rbf/v33nspe1/a95v33nspe1.pdf

PIVETTA, K.F.L.; SARZI, I.; ESTELLITA, M.; BECKMANN-CAVALCANTE, M.Z. Tamanho do diásporo, substrato e temperatura na germinação de sementes de Archontophoenix cunninghamii (Arecaceae). Revista de Biologia e Ciências da Terra, v. 8, n.1, p.126-134, 2008. http://joaootavio.com.br/bioterra/workspace/ uploads/artigos/pivetta-518173973deb6.pdf
THRONEBERRY, G.0.; SMITH, F.G. Relation of respiratory and enzimatic activity to corri seed viability. Plant Physiology, v.30, p.337-43, 1956. http:// www.ncbi.nlm.nih.gov/pmc/articles/PMC540658/

WAGNER JUNIOR, A.; SANTOS, C.E.M.; ALEXANDRE, R.S.; SILVA, J.O.C.; NEGREIROS, J.R.S.; PIMENTEL, L.D.; ÁLVARES, V.S.; BRUCKNER, C.H. Efeito da pré-embebição das sementes e do substrato na germinação e no desenvolvimento inicial do maracujazeirodoce. Revista Ceres, v.54, n.311, p.1-6, 2007. http://www.redalyc.org/ pdf/3052/305226663011.pdf

ZERAIK, M.L.; PEREIRA, C.A.M.; ZUIN, V.G.; YARIWAKE, J.H. Maracujá: um alimento funcional? Revista Brasileira de Farmagnosia, v.20, n.3, p.459-471, 2010. http://www.scielo.br/pdf/rbfar/v20n3/a26v20n3.pdf 